\title{
SUSTAINABLE DEVELOPMENT AND ENERGY SECURITY LEVEL AFTER IGNALINA NPP SHUTDOWN
}

\section{Juozas Augutis ${ }^{1}$, Ričardas Krikštolaitis ${ }^{2}$, Sigita Pečiulyte ${ }^{3}$, Inga Konstantinavičiūtè ${ }^{4}$}

\author{
${ }^{1,2}$ Lithuanian Energy Institute, Laboratory of Nuclear Installation Safety, \\ Breslaujos g. 3, LT-44403 Kaunas, Lithuania \\ ${ }^{1,2,3}$ Vytautas Magnus University, Department of Mathematics and Statistics, \\ Vileikos g. 8, LT-44404 Kaunas, Lithuania \\ ${ }^{4}$ Lithuanian Energy Institute, Laboratory of Energy Systems Research, \\ Breslaujos g. 3, LT-44403 Kaunas, Lithuania \\ E-mails: ${ }^{1}$ juozas@mail.lei.lt; ${ }^{2}$ ricardas@mail.lei.lt (corresponding author);
} ${ }^{3}$ s.peciulyte@if.vdu.lt; ${ }^{4}$ inga@mail.lei.lt

Received 27 May 2010; accepted 24 January 2011

\begin{abstract}
The paper presents the investigation of the impact of Ignalina Nuclear Power Plant (NPP) shutdown on Lithuanian energy security. The system of energy security indicators, covering technical, economic and socio-political aspects is presented. The integral characteristic of these indicators shows the level of energy security. The paper analyses the Lithuanian energy security level in 2007. To make a comparison, the energy security level in 2010, after the shutdown of Ignalina NPP, when Lithuanian Power Plant in Elektrenai becomes the main electricity producer, is forecasted. Two alternatives are analysed: Lithuanian Power Plant uses either gas or heavy fuel oil for electricity production. The security level of each indicator, each indicator block and the total security level are presented as the result. Energy security indicators, which increased or decreased after the shutdown of Ignalina NPP, are analysed, including the indicators which have had the greatest impact on the change in energy security level. The influence of Ignalina NPP shutdown on $\mathrm{CO}_{2}$ emissions is presented. Also, electricity generating costs for different types of electricity production at a different discount rate are presented.
\end{abstract}

Keywords: energy security, security level, system of indicators, Ignalina Nuclear Power Plant (NPP), electricity generating costs, sustainable development.

Reference to this paper should be made as follows: Augutis, J.; Krikštolaitis, R.; Pečiulyte, S.; Konstantinavičiūtė, I. 2011. Sustainable development and energy security level after Ignalina NPP shutdown, Technological and Economic Development of Economy 17(1): 5-21.

JEL Classification: A12, C15, C80, E22. 


\section{Introduction}

Sustainable development has figured prominently in scientific analysis and international policymaking since the early 1990 . The energy sector is central in sustainable development and it affects all aspects of development - social, economic and environmental. Sustainable energy is the provision of energy such that the need of the present without compromising the ability of future generation to meet their needs. A sustainable energy system has been commonly defined in terms of its energy efficiency, its reliability and its environmental impacts. The basic requirements for an energy system are described by Bonser (Bonser 2002). These requirements are following: the ability of an energy system to generate enough power for everybody's need at an affordable price and to help supply the clean, safe and reliable electricity. However the current energy supply in the world is mainly based on limited resources of fossil fuel, which is deemed to be environmentally unsustainable. There is no energy production or conservation technology without risk or without waste. Burning of fossil fuels in electricity and heat generation, transport and industry is the main source of greenhouse gas emissions. To reduce effects of climate change, global greenhouse gas emissions must be reduced significantly. The European Council reached political consensus that an increase of $2{ }^{\circ} \mathrm{C}$ of the earth's average temperature above pre-industrial levels is the maximum 'safe' level that can be envisaged. To achieve $\mathrm{CO}_{2}$ stabilisation at this level, global $\mathrm{CO}_{2}$ emissions need to be cut down to around $10 \mathrm{Gt} / \mathrm{an}$ in 2050 , which is a reduction of around $60 \%$ compared to today's emission levels. Current real world trends partly deviate significantly from the development pathway described in the $2{ }^{\circ} \mathrm{C}$ target scenario, with respect to the continuously growing global energy demand. Performed study showed that strong policy actions is required to close the gap between the well-known climate protection policy commitments and the actual development of the world energy system (Krewitt et al. 2007).

Achieving sustainable economic development on a global scale requires the diversification and use of local energy resources, technologies, appropriate economic incentives and strategic policy planning at the local and national levels (Čiegis et al. 2008). Diversity is an essential element of security and sustainability because concentration of dependence into few sources, technologies or types of fuel inherently increases risks and reduces the flexibility to respond (Ediger et al. 2007). The evaluation of sustainability requires regular monitoring of the impacts of selected policies and strategies to see if they are furthering sustainable development or it is necessary to adjust them (Štreimikienè et al. 2007). In recent studies Giampietro emphasized that science for sustainability policy requires the handling of multicriteria, multi-dimensional, and multi-scale analyses (Giampietro et al. 2006). Multi-criteria analysis methods, which incorporate the use of intelligent support systems, enable a broader perspective, through the use of simple instruments, on the market value measurement process also (Šliogerienè et al. 2009).

The concept of sustainability is usually dealing with the supply side of the energy systems. At the same time some authors gives more emphasis on sustainability of energy consumption (Spreng 2005). Consequently, the main policy issues in order to promote and facilitate a more sustainable energy future are: energy security of supply and availability, energy intensity and efficiency, energy pricing and internalization of externalities, renewable energy sources and etc. (Klevas et al. 2007). 
The Lithuanian National Energy Strategy adopted in 2007 defined the typical characteristics of a sustainable energy system very visibly (National energy...2007):

- Energy security;

- Implementation of EU environmental requirements;

- Efficiency and reliability;

- Regional co-operation and collaboration;

- Increase of the renewable energy sources share;

- Increase of the electricity generated by CHP share;

- Increase of biofuel share;

- Improvements of energy sector management and etc.

Performed studies on integrated sustainability assessment indicators development for monitoring the National sustainable development strategy showed that current implementation of sustainable development targets are successful (Štreimikienè 2007). However, prior to 2010 Lithuania was nuclear power energy producing country. $75 \%$ of the total Lithuanian electricity production consisted of nuclear power energy. Since the very end of year 2009 none of the Ignalina NPP units are in operation. The closure of Ignalina NPP changed the electricity production structure significantly. Now Lithuania has to produce part of electricity in its thermal power plants and to import the other part. The issue of Lithuanian energy security, one of the typical characteristics of a sustainable energy system, relevant up to now, has become even more important and problematic ever since.

As electricity production in the Lithuanian power plant increases gas consumption and, consequently, dependence on it, it is obvious that this factor in its turn decreases the level of energy security. On the other hand, Lithuania can purchase a considerable amount of energy in the free energy market; therefore, an opportunity emerges for other producers of the Lithuanian energy to compete for energy sales, which had not been possible thus far, until Ignalina NPP was functioning selling electricity at a rather low price - barely 7.5 cent per one kilowatt-hour. Apart from that it is expected that the shutdown of NPP will enhance a more rapid development of renewable energy source in Lithuania. These are the factors that increase energy security and have impact on sustainability. The aim of this paper is analysis of Lithuanian energy security level changes after the shutdown of Ignalina NPP. The response to the research question leads to providing an answer to another issue which is the level of energy security and how it can be measured.

Security of energy supply is a complex field of scientific research based on modelling of economical processes, analysis of geopolitical situations, network reliability and resistance to disturbance energy analysis, statistical expertise in emergency situations and violations in energy systems, risk analysis, energy supply problems, technical, social, political and other consequences (Augutis et al. 2008). The result of researches using the following methods is an estimated level of security of energy supply, analysis of consequences, economic and technical optimisation of security protection and uncertainty analysis.

The energy security analysis based on scientific research principles was first started in 1975 by the USA researchers after the increased concern about the growing energy consumption and particularly high amount of imported oil (Generalized Equilibrium...1977). The federal 
government decided to evaluate the security of energy supply and analyse the possibilities of its increase in order to reduce the need for imported oil. One of the core alternatives explored at that time was the production of synthetic fuel. The joint powers of scientists concentrated at Stanford University (USA) started the designing of new methods and software for energy security evaluation. SRI-Gulf model was created based on probability decision tree, which created conditions for the analysis and comparison of numerous scenarios, assessing their likelihood and consequences for energy sector. Besides, the analysis showed that it was inexpedient to change oil products by synthetic fuel at that time.

In the literature various energy security indicators are available and discussed which are considered as measures for assessment of energy security. The World Energy Council has proposed a set of indicators of energy threats. The system is essentially based on the work of Gnansonou (Gnansounou 2006). ECN and the Clingendael Institute of The Netherlands have developed a set of two indicator systems: crisis capability index and supply / demand index (Scheepers et al. 2006). The United Kingdom's White paper establishes the main indicators dealing with security and/or vulnerability of energy system (UK energy...2008). Finnish researchers assessed the energy security by indicators through the facilities of interdependencies and threat analysis (Sivonen 2004). They found that international trade in energy resources, diversification of suppliers, improved intersystem relations, and integrated markets, new energy storages also are a reliable, efficient and economical way to ensure energy independence. The scientists of Joint Research Centre, assessing the risk of energy sector, related indicators with probabilistic analysis (Colli et al. 2008). According their methodology, it is possible to perform risk comparison of all energy technologies in different cycles using Probabilistic Safety Assessment methods. Dutch scientists overviewed indicators found in the literature (Kruyt et al. 2009). They considered that most indicators had a much more heuristic role - capturing a particular aspect of security of supply and indicating a relative position or direction of change. Other researchers suggested all indicators distinguish in two groups: so-called "ex-post" and "ex-ante" indicators. First group of indicators are used to assess whether energy security existed in the past, while the second one - to estimate how energy (in-) security may evolve in the future (Löschel et al. 2010).

The European Union (EU) is one of the most active developers of energy security assessment methods and assurance measures. Its initiatives expressed in the directives to increase the percentage of renewable energy resource in the common energy balance up to $20 \%$, to reduce energy consumption by $20 \%$, to reduce greenhouse gas emissions by $20 \%$ up to 2020 would lead to a drastic reduction of EU energy dependence on import. "NABUCO" project as an alternative to Russian gas supply would allow the diversification of gas supply and reduction of EU dependence on its main supplier - Russia. In general, these mentioned EU targets has influence not only on security issues but on sustainable development also.

Today the concept of security of energy supply is much more expanded in comparison with its initial understanding in the seventies and includes more aspects than prior definitions. First of all, some authors consider energy security in geopolitical context related to only gas supply (Bilgin 2009); while others consider that energy security covers analysis of several sources of energy (Le Coq and Paltseva 2009). Another important aspect is environmental issues which have become a very important element limiting the reliability of energy. The 
main international documents that regulate the change of climate are the United Nations Framework Convention on Climate Change and Kyoto Protocol (Kyoto protocol...1998). According to Kyoto Protocol, Lithuania committed itself during the period of 2008-2012 to reduce the amount of greenhouse gas emission by $8 \%$, comparing with pollution level in 1990. In the packet of law acts on climate change and energy, approved in December 2008, it is planned up to 2020 to base the energy policy on the commitment to reduce the greenhouse gas emissions by $20 \%$ in comparison with 1990 (European Parliament...2008). New and increasingly strict limitations inevitably narrow the range of choice of fuel kinds. Various issues of environment security energy sector were broadly analysed in the Fourth Assessment Report of the Intergovernmental Panel on Climate Change (Climate change...2007). The concern about security of energy supply and global climate change has been revives interest in nuclear power. Nuclear power could make a significant contribution towards greenhouse gas emission reduction (Adamantiades and Kessides 2009). In the context of sustainable energy system, in the side of security, the efficient use of local and renewable energy sources, the regional co-operation is very important.

\section{Electricity generating costs}

Sustainable energy development and energy security is often required actions and remedies which in short-term perspective are not competitive and cost-effective. As criteria of sustainable development and energy security it is necessary to investigate investments and variation of energy costs, which are the result of remedies to ensure sustainable development and energy security. This section presents nuclear energy production costs in comparison with generation from coal and gas.

The structure of total generation costs (i.e. share of investment, operation and maintenance (O\&M) and fuel costs) differs markedly among the different plant types, as shown in Table 1 .

Because of their cost structures, the sensitivity of total generation costs to changes in fuel prices differs strongly among plant types. A doubling of fuel prices would increase generation costs by about $40 \%$ for coal, $75 \%$ for gas and $4 \%$ for nuclear (a doubling of uranium price only). Nuclear generation costs would increase by $15 \%$ if the cost of the entire fuel cycle were to double, but it should be noted that the costs of fuel cycle services, delivered by industrial facilities, are more stable than those of raw materials.

Capital investment costs include the "overnight" construction costs (the actual spending on construction materials and labour) and interest during construction (IDC). The IDC depends on the local economic context and on the financing mode of the project, but it

Table 1. Generation cost structure

\begin{tabular}{lcccccc}
\hline \multirow{2}{*}{ Cost component } & \multicolumn{3}{c}{ At 5\% discount rate } & \multicolumn{3}{c}{ At 10\% discount rate } \\
\cline { 2 - 8 } & Nuclear & Coal & Gas & Nuclear & Coal & Gas \\
\hline Investment & 50 & 35 & 15 & 70 & 50 & 20 \\
\hline O\&M & 30 & 20 & 10 & 20 & 15 & 7 \\
\hline Fuel & 20 & 45 & 75 & 10 & 25 & 73 \\
\hline
\end{tabular}


also depends on the technology, construction time and direct cost of the plant. In situations where a decommissioning fund has to be set aside before the commissioning of the plant, decommissioning costs are included in the capital investment cost.

Operation and maintenance costs include all the running costs not associated with the fuel cycle, e.g. maintenance materials, manpower and services, insurance, operational waste management and disposal. Expenses associated with safety inspections and safeguards controls are included in O\&M costs as well. Decommissioning costs are also included in the O\&M costs when the decommissioning fund is provisioned progressively over the lifetime of the plant.

Fuel cycle costs include all the expenses associated with the entire fuel cycle, from uranium acquisition to spent fuel and/or high-level waste disposal. Except for natural uranium, the costs associated with each step of the fuel cycle correspond to services (e.g. conversion, enrichment and fuel fabrication) delivered by industrial facilities, and they are much less volatile than commodity prices.

In 2010 it was published the study "Projected Costs of Generating Electricity - 2010 Edition" (International Energy Agency 2010) where it was presented the main results of the work carried out in 2009 for calculating the costs of generating baseload electricity from nuclear and fossil fuel thermal power stations as well as the costs of generating electricity from a wide range of renewable technologies, some of them with variable or intermittent production. The study focuses on the expected plant-level costs of baseload electricity generation by power plants that could be commissioned by 2015. In this study two important conclusions were reached (Table 2). First, in the low discount rate case, more capital-intensive, low-carbon technologies such as nuclear energy are the most competitive solution compared with coalfired plants without carbon capture and natural gas-fired combined cycle plants for baseload generation. It should be emphasized that these results incorporate a carbon price of USD 30 per tonne of $\mathrm{CO}_{2}$, and that there are great uncertainties concerning the cost of carbon capture, which has not yet been deployed on an industrial scale.

Table 2. Levelised costs of electricity for European countries

\begin{tabular}{|c|c|c|c|c|c|c|c|c|}
\hline \multirow{2}{*}{$\begin{array}{l}\text { Levelised costs } \\
\text { of electricity, } \\
\text { USD/MWh }\end{array}$} & \multicolumn{4}{|c|}{ At $5 \%$ discount rate } & \multicolumn{4}{|c|}{ At $10 \%$ discount rate } \\
\hline & Nuclear & $\begin{array}{l}\text { Coal with } \\
\text { CC }(S)\end{array}$ & $\begin{array}{l}\text { Coal without } \\
\text { CC }(S)\end{array}$ & Gas & Nuclear & $\begin{array}{c}\text { Coal with } \\
\text { CC(S) }\end{array}$ & $\begin{array}{l}\text { Coal without } \\
\text { CC }(S)\end{array}$ & Gas \\
\hline Median & 62.59 & 107.28 & 83.43 & 89.71 & 105.06 & 138.38 & 88.49 & 98.29 \\
\hline Minimum & 49.97 & 87.41 & 70.29 & 80.4 & 60.23 & 94.6 & 68.06 & 86.48 \\
\hline Maximum & 81.65 & 141.64 & 120.01 & 118.77 & 136.5 & 152.27 & 102.59 & 122.61 \\
\hline
\end{tabular}

Second, in the high discount rate case, coal without carbon capture equipment $(\mathrm{CC}(\mathrm{S}))$, followed by coal with $\mathrm{CC}(\mathrm{S})$, and gas-fired combined cycle turbines, are the cheapest sources of electricity. In the high discount rate case, coal without $\mathrm{CC}(\mathrm{S})$ is always cheaper than coal with $\mathrm{CC}(\mathrm{S})$, even in low-cost coal regions, at a carbon price of USD 30 per tonne. The results highlight the paramount importance of discount rates and, to a lesser extent, carbon and fuel prices when comparing different technologies. 


\section{The algorithm of energy security level assessment}

The security of energy supply assessment algorithm using indicators can be briefly outlined as: developing of data; gathering of the factual indicator values; calculation or expert assessment of indicators' threshold values; calculation of normalized indicators values; creation of each indicator critical scale; assessment of each indicator in points by critical scale; evaluation of every indicator changes dynamics during the researching period; assessment of state of block and whole object, which is under consideration (energy system, region, country, enterprise, etc.); uncertainty analysis of the data, sensitivity and importance analysis of indicators weight; presentation of recommendations regarding security level support and improvement. Security indicator is a special index which gives numerical values to important issues for security of energy sector.

Each indicator is described by presenting a title, factual, threshold pre-critical ( $\left.p c t v_{i j k}\right)$ and critical ( $\left.c t v_{i j k}\right)$ state values (Augutis et al. 2009). All indicators are measured in percents. Threshold values indicate when the researched system changes to pre-critical and critical states. These threshold values are identified on the basis of technical regulations, normative documents of equipment exploitation and expert assessment in percents. Factual value of each indicator is denoted as $X_{i j k}$, where $I=1, \ldots, n$ - block number, $j=1, \ldots, m$ - group number in the block, $k=1, \ldots, l$-indicator number in the group.

In order to identify the state of the system each indicator should be evaluated in points. In this purpose we construct evaluation scale for each indicator (see Fig. 1). Creating the evaluation scale it is important a direction of indicators values: increasing, when $p c t v_{i j k}>c t v_{i j k}$ (e. g. the indicator $X_{114}$ "Average ratio of power units lifetime with their technical resource time"); decreasing, when $p c t v_{i j k}<c t v_{i j k}$ (e. g. the indicator $X_{112}$ "Ratio of the biggest power plant capacity to installed capacity of the whole system"). In the first case a higher value of the indicator corresponds to a higher level of security, in the second - to the lower. Pre-critical and critical threshold values divide increasing and decreasing scales of indicators factual values into three parts: normal, pre-critical and critical states. These three states are further subdivided into five equal parts accordingly. After that each state is assigned by points from 1 to 15 : normal state $-11-15$ points; pre-critical state $-6-10$ points; critical state $-1-5$ points.

The value of each indicator is evaluated by points from 1 to 15 during the research year and it is defined $X_{i j k}^{p}$. If the direction of the indicator's scale is decreasing, the state of the

\section{Energy Supply Security Evaluation Scale}

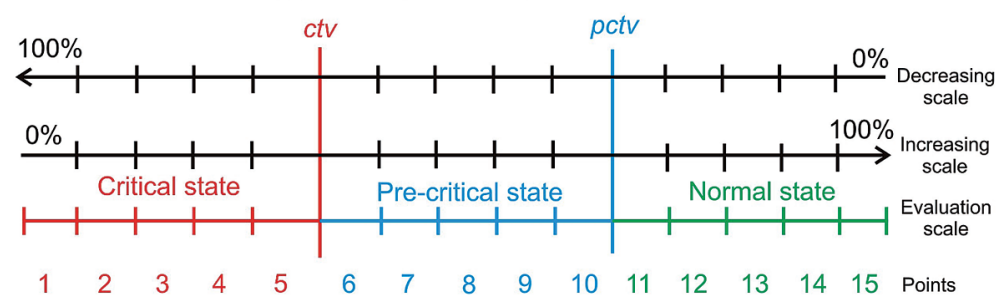

Fig. 1. Scale of energy supply security state assessment 
indicator is considered normal, when indicator's value is $X_{i j k}<p c t v_{i j k}$; pre-critical, when $p c t v_{i j k} \leq X_{i j k} \leq c t v_{i j k}$; and critical, when $X_{i j k}>c t v_{i j k}$. If the direction of the indicator's scale is increasing the state is normal, when the indicator's value is $X_{i j k}>p c t v_{i j k}$; pre-critical, when $c t v_{i j k} \leq X_{i j k} \leq p c t v_{i j k}$; critical, when $X_{i j k}<c t v_{i j k}$.

Further it is calculated or determined by expert assessment method each indicator's weight in the group $s_{i j k}$, the weight of the group in the block $s_{i j}$ and block weight $s_{i}$, here $I=1, \ldots, n$, $j=1, \ldots, m, k=1, \ldots, l$. The state of security of energy supply is evaluated taking into account the weights of blocks, groups and indicators according to the formula:

$$
B=\sum_{i=1}^{n}\left(s_{i} \sum_{j=1}^{m}\left(s_{j} \sum_{k=1}^{l} s_{i j k} X_{i j k}^{p}\right)\right) .
$$

\section{Energy security level assessment}

To achieve the aim of the work, i.e. to assess the impact of Ignalina NPP shutdown upon the energy security in Lithuania, a system of energy security indicators was created.

1. Technical block

\subsection{Electricity}

1.1.1. Ratio of total installed power capacity of generators and connections lines to maximal power demand $\left(X_{111}\right)$.

1.1.2. Ratio of the biggest power plant capacity to installed capacity of the whole system $\left(X_{112}\right)$.

1.1.3. Share of maximum installed part of one technology in the total production of electricity $\left(X_{113}\right)$.

1.1.4. Average ratio of power units lifetime with their technical resource time $\left(X_{114}\right)$.

\subsection{Gas}

1.2.1. Ratio of total capacity of pipeline to maximum gas consumption $\left(X_{121}\right)$.

1.2.2. Ratio of gas amount which can be stored in gas storages to average annual consumption $\left(X_{122}\right)$.

1.2.3. Ratio of the biggest gas supply facility capacity to average consumption $\left(X_{123}\right)$.

1.3. Oil

1.3.1. Ratio of the potential supply of oil and its products to Lithuania to average annual consumption $\left(X_{131}\right)$.

1.3.2. Ratio of the capacity of the largest supplier of oil and its products to annual consumption $\left(X_{132}\right)$.

1.3.3. Ratio of accumulated oil products reserves amount to average annual consumption $\left(X_{133}\right)$.

1.4. Coal

1.4.1. Ratio of technical capacities of coal supply to annual demand ( $\left.X_{141}\right)$. 
1.4.2. Ratio of the capacity of the largest coal supplier to annual coal demand $\left(X_{142}\right)$.

1.4.3. Ratio of accumulated coal reserves amount to average annual consumption $\left(X_{143}\right)$.

\subsection{Nuclear fuel}

1.5.1. Ratio of technical possibilities of nuclear fuel supply to annual demand $\left(X_{151}\right)$.

1.5.2. Ratio of the capacity of used nuclear fuel repository to demand (during assessment) $\left(X_{152}\right)$.

1.5.3. Ratio of the accumulated nuclear fuel amount to average annual consumption $\left(X_{153}\right)$.

1.6. Biofuel

1.6.1. Ratio of the capacity of biofuel production to annual consumption of biofuel $\left(X_{161}\right)$.

1.6.2. Ratio of the capacity of the largest biofuel producer to annual consumption $\left(X_{162}\right)$.

1.6.3. Ratio of accumulated biofuel reserves amount to average annual consumption $\left(X_{163}\right)$.

1.7. Heat

1.7.1. Ratio of the total capacity of the installed heat generators to maximal heat demand $\left(X_{171}\right)$.

1.7.2. Average ratio of average power units lifetime to their technical resource time $\left(X_{172}\right)$.

1.7.3. Share of one heat production technology which produces most heat in the total heat production $\left(X_{173}\right)$.

1.7.4. Percentage of heat production which can be replaced by another kind of fuel without changing technology $\left(X_{174}\right)$.

2. Economic block

\subsection{Electricity}

2.1.1. Ratio of the amount of electricity purchased in the electricity market to average annual demand for electricity $\left(X_{211}\right)$.

2.1.2. Share of consumers who choose the producer of electricity freely $\left(X_{212}\right)$.

2.1.3. Ratio of the amount of electricity which can be produced using fuel imported only from one supplier to the total amount of produced electricity $\left(X_{213}\right)$.

2.1.4. Ratio of the imported electricity amount to annual demand for electricity $\left(X_{214}\right)$.

2.2. Gas

2.2.1. Ratio of gas amount purchased in the gas market to average annual gas consumption $\left(X_{221}\right)$.

2.2.2. Possibility for consumers to choose a gas supplier $\left(X_{222}\right)$. 
2.2.3. Share of the imported gas from the single possible supplier $\left(X_{223}\right)$.

2.2.4. Ratio of the imported gas amount to average annual gas consumption $\left(X_{224}\right)$. 2.3. Oil

2.3.1. Ratio of the amount of oil purchased in the oil market to average annual oil consumption $\left(X_{231}\right)$.

2.3.2. Possibility for consumers to choose an oil supplier $\left(X_{232}\right)$.

2.3.3. Share of imported oil from a single supplier $\left(X_{233}\right)$.

2.3.4. Ratio of the imported oil amount to average annual oil consumption $\left(X_{234}\right)$.

2.4. Coal

2.4.1. Ratio of the amount of coal, purchased on coal market to average annual coal consumption $\left(X_{241}\right)$.

2.4.2. Possibility for consumers to choose a coal supplier $\left(X_{242}\right)$.

2.4.3. Share of the imported coal from a single possible supplier $\left(X_{243}\right)$.

2.4.4. Ratio of the amount of imported coal to average annual coal consumption $\left(X_{244}\right)$.

2.5. Nuclear fuel

2.5.1. Ratio of the amount of nuclear fuel purchased in the nuclear fuel market to average annual nuclear fuel consumption $\left(X_{251}\right)$.

2.5.2. Possibility for electricity producers to choose a nuclear fuel supplier $\left(X_{252}\right)$.

2.5.3. Share of the imported nuclear fuel from a single possible supplier $\left(X_{253}\right)$.

2.5.4. Ratio of the amount of the imported nuclear fuel to average annual nuclear fuel consumption $\left(X_{254}\right)$.

2.6. Biofuel

2.6.1. Ratio of the amount of biofuel purchased in the biofuel market to average annual biofuel consumption $\left(X_{261}\right)$.

2.6.2. Possibility for consumers to choose a biofuel supplier $\left(X_{262}\right)$.

2.6.3. Share of biofuel from a single possible supplier $\left(X_{263}\right)$.

2.6.4. Ratio of the amount of the imported biofuel to the total consumed amount of biofuel $\left(X_{264}\right)$.

2.7. Heat

2.7.1. Possibility for consumers to choose a heat supplier $\left(X_{271}\right)$.

2.7.2. Ratio of the amount of heat produced using the fuel which is possible to be imported from a single supplier to the total amount of heat $\left(X_{272}\right)$.

2.7.3. Ratio of the amount of the own national fuel, used for the production of heat to the total consumed amount of fuel $\left(X_{273}\right)$.

3. Socio-political block

\subsection{Geopolitics}

3.1.1. The biggest share of the amount of energy resources imported from a single country in the general energy consumption balanced $\left(X_{311}\right)$. 
3.1.2. Weighted mean (according to the size of import) of political risk factors from the countries energetic resources are imported from $\left(X_{312}\right)$.

3.1.3. Weighted mean (according to the size of transit) of political risk factors of transit countries energy resources are imported through $\left(X_{313}\right)$.

3.1.4. Weighted mean (according to the size of invested capital) of political risk factors of foreign states that have invested into national energy no less than $10 \%$ of the energy system wealth $\left(X_{314}\right)$.

3.1.5. Weighted mean (according to the size of connections) of political risk factors of the countries that electricity transmission network is connected with $\left(X_{315}\right)$.

3.1.6. Political risk factor of the country itself $\left(X_{316}\right)$.

3.2. Socio-politics

3.2.1. Average expenses for energy per inhabitant in comparison with average annual income $\left(X_{321}\right)$.

3.2.2. Degree of undertaking the commitment with regard to renewables in the total final consumption $\left(X_{322}\right)$.

3.2.3. Degree of following the requirements of Kyoto protocol regarding the reduction of greenhouse gas emission $\left(X_{323}\right)$.

3.2.4. Degree of undertaking the commitment regarding energy saving $\left(X_{324}\right)$.

3.2.5. Positive societal assessment concerning the development of nuclear power energy in the country $\left(X_{325}\right)$.

Data for indicator systems can be received from statistical data, economical modelling, reliability modelling or experts' judgment, social/political assessment, which often is based on hypothetical probabilities received from lognormal distribution.

Assessing the energy security level of Lithuania before and after the shutdown of Ignalina NPP, at first indicator groups was constructed and group weights determined. Three indicator blocks were created: technical block, economical block and socio-political block. Equal weights were attributed to all three blocks $s_{i}=1 / 3, i=1,2,3$ assuming that they have equal impact upon the level of energy security.

Technical and economic indicator block groups were distinguished according to the kind of fuel used in the energy system. Electricity and heat were included in the composition of these indicators' blocks additionally as separate groups of indicators. Indicator group weights in the technical and economical blocks were identified according to each kind of fuel and electricity, as well as heat consumption, calculating the part of relative oil fuel equivalents by thousands of tons in the total energy consumption. Group weights change depending on the year of assessment (2007 and 2010) (Table 3). The weights for indicators in 2010 are presented for two scenarios - when Lithuanian Power Plant uses gas and heavy fuel oil for electricity production. The weights of socio-political block were determined as equal: $s_{31}=s_{32}=1 / 2$.

Presenting the indicators of the technical block technical and reliability parameters were taken into account, emphasizing the capacity of fuel supply to Lithuania, annual or maximum demands, energy generators lifetime and accumulated fuel reserves. 
Table 3. Weights of groups in technical and economic blocks $(i=1,2)$

\begin{tabular}{lccccc}
\hline \multicolumn{1}{c}{ Group } & Year & & 2007 & 2010 Gas & 2010 Heavy fuel oil \\
\cline { 1 - 2 } Electricity & $s_{i 1}$ & 0.1934 & 0.1659 & 0.1645 \\
\hline Gas & $s_{i 2}$ & 0.2862 & 0.4078 & 0.3606 \\
\hline Oil & $s_{i 3}$ & 0.0456 & 0.0579 & 0.1096 \\
\hline Coal & $s_{i 4}$ & 0.0365 & 0.0469 & 0.0465 \\
\hline Nuclear power & $s_{i 5}$ & 0.1357 & 0 & 0 \\
\hline Biofuel & $s_{i 6}$ & 0.1141 & 0.1598 & 0.1585 \\
\hline Heat & $s_{i 7}$ & 0.1885 & 0.1617 & 0.1603 \\
\hline
\end{tabular}

Forming the indicators of economic block most attention was paid to annual demand for appropriate kind of fuel, a possibility to choose fuel suppliers freely, diversification of fuel suppliers, and the ratio of the imported fuel to annual consumption.

The socio-political block was divided into two groups: geopolitical indicators and sociopolitical indicators. The aim of geopolitical indicators is to assess political ratings, announced on the international scale, of the national country and foreign countries, the energy resources are supplied from and through by transit. The distribution of the capital in the energy sector is also taken into account. Indicating the values of geopolitical indicators 12 factors exert impact (International Country...2009): government stability; socio-economical state; investment conditions; internal conflicts; external conflicts, corruption in the country; impact of the army upon politics; impact of religion; law and order; ethnical tension; level of democracy; quality of bureaucracy. The aim of socio-political indicators is to present the implementation of the assumed international obligations and EU directives on the part of the assessed country, the ratio of energy consumption to gross domestic product.

The weights $s_{i j k},(i=\overline{1, n}, j=\overline{1, m}, k=\overline{1, l})$ of indicators within each group were determined as equal.

Taking into consideration the assessment of indicators by points, their weights in groups and group weights, the energy security level of Lithuania was determined according to separate indicator blocks (on 15 point scale). The results are presented in Table 4.

The total level of energy security calculated using (1) formula was 7.24 points in 2007. Calculating according to the scenario, when gas was used in the Lithuanian Power Plant in

Table 4. Assessment of block security state in points

\begin{tabular}{|c|c|c|c|}
\hline Year & \multirow{2}{*}{2007} & \multirow{2}{*}{2010 gas } & \multirow{2}{*}{2010 heavy fuel oil } \\
\hline Block & & & \\
\hline Technical & 9.20 & 8.16 & 9.30 \\
\hline Economical & 6.03 & 6.11 & 6.44 \\
\hline Socio-political & 6.50 & 6.60 & 6.60 \\
\hline Total & 7.24 & 6.96 & 7.45 \\
\hline
\end{tabular}


2010, energy security level decreased to 6.96 points; whereas using heavy fuel oil, energy security level increased up to 7.45 points. Thus, the total energy security level in all cases falls into the pre-critical state. It is important to note that having shut down the Ignalina NPP, energy security level of Lithuania has not changed essentially. Still a thorough explanation of this fact requires the analysis of separate indicators.

The obtained research findings indicate that the highest impact upon the energy security level is exerted by four indicators. Three of these indicators - "Share of maximum installed part of one technology in the total production of electricity", "Ratio of total capacity of pipeline to maximum gas consumption" (only with regard to 2010 gas scenario) and "Ratio of the imported electricity amount with annual demand for electricity" - reduce the level of energy security. The indicator "Share of consumers who choose the producer of electricity freely" increases the level of energy security. The points of other eleven indicators change inconsiderably and do not affect the general change in energy security level (Figs 2 and 3).

Further a brief discussion of indicators that exert most impact will be presented. The indicator "Share of maximum installed part of one technology in the total production of electricity" indicates the part of prevailing technology in electricity production. In 2007, it was Ignalina NPP, whereas in 2010, in case of gas scenario, power plants heated by gas prevail; in the scenario "2010 heavy fuel oil" - power plants heated by heavy fuel oil prevail. As gas supply is most sensitive to technical disturbances and economic factors (e.g., sharp growth in prices) as well as to geo-political factors (e.g., arguments between Russia and Belarus regarding gas transit), then the dominance of this kind of fuel in energy production decreases energy security. Besides, the increased gas supply also has a negative impact upon energy security level as gas can be supplied only by one pipeline and only by one supplier - Russia. The import of more significant amount of electricity which emerged after the shutdown of Ignalina NPP has an essentially negative impact upon energy security, though the situation is slightly smoothed over by a possibility to buy electricity in the market more cheaply than it is possible to produce in Lithuania. On the other hand, the opportunity that emerged for a

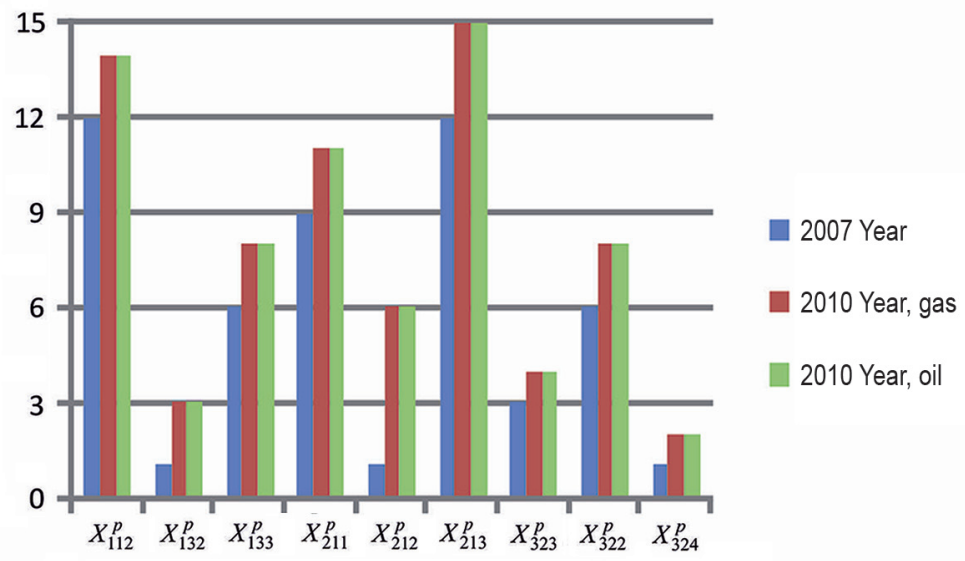

Fig. 2. Indicators that increase energy security level 


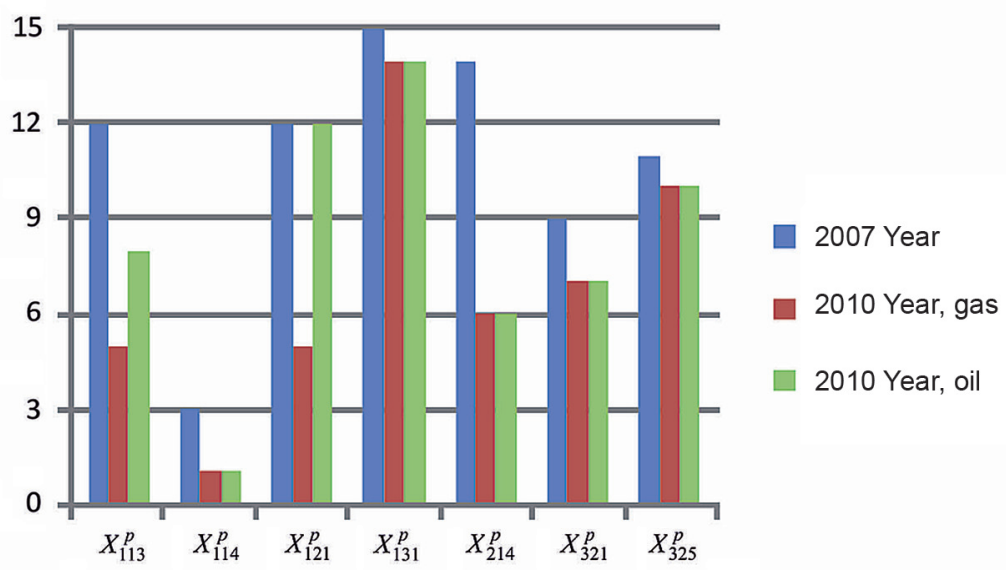

Fig. 3. Indicators that decrease energy security level

greater part of consumers after the shutdown of Ignalina NPP to choose the supplier or buy the electricity in the market has improved the values of this indicator, comparing with the situation before the shutdown of the nuclear power plant. Thus it is evident that the shutdown of Ignalina NPP has had a twofold impact upon the energy security level of Lithuania: some security indicators improved while others fell off; therefore, the general change in the energy security level since the shutdown of Ignalina NPP has been insignificant.

Having shut down Ignalina NPP, the dependence of the Lithuanian energy sector will increase and the emission of pollution to the atmosphere will also rise. The changed electricity production structure will lead to the emission of greenhouse gas to the atmosphere. After the closure of the second block of Ignalina NPP the emission of $\mathrm{CO}_{2}$ can increase by 6-7 mln. t. (Galinis et al. 2008). The possibly different development of energy sector will inevitably cause different greenhouse gas emissions. However, aiming at the reduction of greenhouse gas emission, the scale of fossil fuel to be chosen becomes rather narrow. With regard to the emissions of $\mathrm{CO}_{2}$ the use of natural gas becomes one of the best solutions, as this fuel ensures the lowest greenhouse gas emissions out of all kinds of organic fuel. Burning heavy oil fuel, about $0.3 \mathrm{t} / \mathrm{MWh}$ greenhouse gas is produced, whereas burning natural gas $-0.2 \mathrm{t} / \mathrm{MWh}$. The amount of greenhouse gas produced while burning natural gas is approximately $30 \%$ less than burning heavy oil fuel. Thus, with regard to pollution the closure of Ignalina NPP exerts a negative impact. In order to promote sustainable energy future and reduce the negative impact of increase air pollution it is necessary to enhance utilization of renewable energy sources and increase energy efficiency.

\section{Conclusions}

According to this methodology, energy security level in 2007 is approximately 7.3 in a fifteenpoint system. Comparing to this in scenario when gas it is using in the Lithuanian Power Plant in 2010, energy security level is decreasing to 6.96 points; whereas using heavy fuel oil, 
energy security level is increasing up to 7.45 points. Netherless, in all three cases estimated security level reach in a pre-critical energy system level.

Summarising the investigations it is possible to note that the closure of Ignalina NPP has had a multifaceted impact upon energy security of Lithuania. Diversity of fuel is an essential element of security and sustainability because concentration of dependency on few energy sources increases risks and reduces flexibility of system.

It is natural that part of energy security indicators decreased after the shutdown of Ignalina NPP. It is, first of all, related to the increased gas export and higher prices for electricity energy. However, the shutdown of Ignalina NPP has also had some positive consequences for energy security of Lithuania. First, the withdrawal of Ignalina NPP from the Lithuanian electricity sector created conditions for the development of free electricity market and higher numbers of consumers were provided with possibilities to choose electricity producers. Second, the competition among other producers of electricity and higher motivation to develop renewables that emerged after the shutdown of Ignalina NPP can be assessed as another positive factor.

Having summarised positive and negative consequences of the shutdown of Ignalina NPP according to the methodology of indicators proposed in this work, it is possible to draw a conclusion that the shutdown of Ignalina NPP has changed the energy security level of Lithuania inconsiderably.

\section{Acknowledgement}

This research was funded by a grant (No. ATE-08/2010) from the Research Council of Lithuania.

\section{References}

Adamantiades, A.; Kessides, I. 2009. Nuclear power for sustainable development: Current status and future prospects, Energy Policy 37(12): 5149-5166. doi:10.1016/j.enpol.2009.07.052

Augutis, J.; Krikštolaitis, R.; Matuzienè, V.; Pečiulytė, S. 2009. Assessment of energy supply security indicators for Lithuania, in Safety, Reliability and Risk Analysis: Theory, Methods and Applications: Proceedings of the European Safety and Reliability Conference (ESREL 2008), Valencia, Spain, September 22-25, 2008. London: CRC Press Taylor \& Francis Group, 2575-2580.

Augutis, J.; Matuzienè, V.; Krikštolaitis, R.; Pečiulytė, S.; Norvaiša, E. 2008. Energijos tiekimo saugumo vertinimo metodų analizė [Analysis of Security of Energy Supply Assessment Methods], Energetika 54(4): 1-9.

Bilgin, M. 2009. Geopolitics of European natural gas demand: Supplies from Russia, Caspian and the Middle East, Energy Policy 37(11): 4482-4492. doi:10.1016/j.enpol.2009.05.070

Bonser, D. 2002. Nuclear Now for Sustainable Development. Annual Symposium 2002. The World Nuclear Association.

Climate change 2007: Mitigation of climate change. Contribution of Working Group III to the Fourth Assessment Report of the IPCC. 2007. Cambridge University Press. 851 p.

Colli, A.; Serbanescu, D.; Ale, B. J. M. 2008. Indicators to compare risk expressions, grouping, and relative ranking of risk for energy systems: Application with some accidental events from fossil fuels, Safety Science 47(5): 591-607. doi:10.1016/j.ssci.2008.07.022

Čiegis, R.; Gavenauskas, A.; Petkevičiūtè, N.; Štreimikiene, D. 2008. Ethical values and sustainable development: Lithuanian experience in the context of globalisation, Technological and Economic Development of Economy 14(1): 29-37. doi:10.3846/2029-0187.2008.14.29-37 
Galinis, A.; Konstantinavičiūtè, I.; Miškinis, V.; Alèbaitė, I. 2008. Forecast of greenhouse gas emissions development in Lithuania by 2020, in Electrical and Control Technologies ECT-2008: Proceedings of the 3rd International Conference, Kaunas University of Technology, May 8-9, 2008. Kaunas: Technologija, 341-344.

Giampietro, M.; Mayumi, K.; Munda, G. 2006. Integrated assessment and energy analysis: quality assurance in multi-criteria analysis of sustainability, Energy 31(1):59-86. doi:10.1016/j.energy.2005.03.005

Gnansounou, E. 2006. Monitoring the vulnerability of energy supply system, in Proc. of the 15th Energy Day in Croatia - Energy Policy Scenarios for 2050, 26 November, 2006. Zagreb.

Ediger, V.; Hosgor, E.; Surmeli, N.; Tatlidil, H. 2007. Fossil fuel sustainability index: An application of resource management, Energy Policy 35(5): 2969-2977. doi:10.1016/j.enpol.2006.10.011

European Parliament Legislative Resolution of 17 December 2008 on the Proposal for a Decision of the European Parliament and of the Council on the Effort of Member States to Reduce their Greenhouse Gas Emissions to meet the Community's Greenhouse Gas Emission Reduction Commitments up to 2020. Available from Internet: <www.europarl.europa.eu>.

Generalized Equilibrium Modeling: The Methodology of the SRI-GULF Energy Model. 1977. Prepared by Cazalet E. G. and Stanford Research Institute. Final Report.

International Country Risk Guide, Copyright. 1984-Present. The PRS Group, Inc. Available from Internet: $<$ www.prsgroup.com>.

International Energy Agency, Nuclear Energy Agency. Projected costs of generating electricity. 2010 edition.

Kyoto protocol to the United Nations Framework Convention on Climate Change. 1998. Available from Internet: <unfccc.int/resource/docs /convkp/kpeng.pdf>.

Klevas, V.; Štreimikienė, D.; Grikštaite, R. 2007. Sustainable energy policy in the Baltic states, Energy Policy 35(1): 76-90. doi:10.1016/j.enpol.2005.10.009

Krewitt, W.; Simon, S.; Graus, W.; Teske, S.; Zervos, A.; Schafer, O. 2007. The $2{ }^{\circ} \mathrm{C}$ scenario - A sustainable world energy perspective, Energy Policy 35(10): 4969-4980. doi:10.1016/j.enpol.2007.04.034

Kruyt, B.; van Vuuren, D. P.; de Vries, H. J. M.; Groenenberg, H. 2009. Indicators for energy security, Energy Policy 37(6): 2166-2181. doi:10.1016/j.enpol.2009.02.006

Le Coq, C.; Paltseva, E. 2009. Measuring the security of external energy supply in the European Union, Energy Policy 37(11): 4474-4481. doi:10.1016/j.enpol.2009.05.069

Löschel, A.; Moslener, U.; Rübelke, D. T. G. 2010. Indicators of energy security in industrialised countries, Energy Policy 38(4): 1665-1671. doi:10.1016/j.enpol.2009.03.061

National Energy Strategy. 2007-01-18, No. X-1046. Official Gazette 2007, No.11-430.

Nuclear Energy Agency. Nuclear Energy Outlook 2008, OECD Publishing, 2008.

Scheepers, M.; Seebregts, A.; de Jong, J. \& Maters, H. 2006. EU standards for energy security of supply. Available from Internet: <www.clingendael.nl/publications/2006/20060600_ciep_misc_dejongmaters-et-al.pdf>.

Sivonen, H. 2004. Calculating Compound Risk of Failure Based on Interdependencies of Critical Infrastructures, in EAPC/PfP Workshop on Critical Infrastructure Protection and Civil Emergency Planning, 9-11 September, 2004, Zurich.

Spreng, D. 2005. Distribution of energy consumption and the $2000 \mathrm{~W} /$ capita target, Energy Policy 33: 1905-1911. doi:10.1016/j.enpol.2004.03.023

Šliogerienė, J.; Kaklauskas, A.; Zavadskas, E. K.; Bivainis, J.; Seniut, M. 2009. Environment factors of energy companies and their effect on value: analysis model and applied method, Technological and Economic Development of Economy 15(3): 490-521. doi:10.3846/1392-8619.2009.15.490-521

Štreimikiene, D. 2007. Monitoring of energy supply sustainability in the Baltic Sea region, Energy Policy 35(3): 1658-1674. doi:10.1016/j.enpol.2006.05.011 
Štreimikiené, D.; Čiegis, R.; Grundey, D. 2007. Energy indicators for sustainable development in Baltic States, Renewable and Sustainable Energy Reviews 11(5): 877-893. doi:10.1016/j.rser.2005.06.004

UK Energy Sector Indicators 2008. Bureu of Business, Enterprise and Regulatory Reform, 2008. Available from Internet: <www.berr.gov.uk/files/file48502.pdf >.

\section{DARNI PLĖTRA IR ENERGETINIO SAUGUMO LYGIS PO IGNALINOS AE UŽDARYMO}

\section{J. Augutis, R. Krikštolaitis, S. Pečiulytė, I. Konstantinavičiūtė}

Santrauka. Straipsnyje nagrinejama Ignalinos atominès elektrinès (AE) uždarymo ịtaka Lietuvos energetiniam saugumui. Darbe pateikiama energetinio saugumo indikatorių sistema, apimanti techninius, ekonominius ir sociopolitinius aspektus. Šių indikatorių integralinè charakteristika ir parodo energetinio saugumo lygi. Straipsnyje nagrinejamas Lietuvos energetinis saugumo lygis 2007 metais ir palyginimui prognozuojamas energetinio saugumo lygis 2010 metais po Ignalinos AE uždarymo, kai pagrindine elektros gamintoja tampa Lietuvos elektrinè. Analizuojamos dvi alternatyvos: Lietuvos elektrinè elektros gamybai naudoja dujas arba mazutą. Nurodomas kiekvieno indikatoriaus saugumo balas, kiekvieno bloko ir bendras saugumo lygis visais nagrinejjamais atvejais. Analizuojama, kurie energetinio saugumo indikatoriai pagerejo ir kurie pablogejo po Ignalinos AE uždarymo, kurie turèjo didžiausią ịtaką energetinio saugumo lygio pasikeitimui. Nagrinejama, kaip Ignalinos $\mathrm{AE}$ uždarymas veikia $\mathrm{CO}_{2}$ emisijos pasikeitimą, nurodoma elektros gamybos kaina esant skirtingiems elektros gamybos būdams ir skirtingai diskonto normai.

Reikšminiai žodžiai: energetinis saugumas, saugumo lygis, indikatorių sistema, Ignalinos atominė elektriné, elektros gamybos kaina, darni plètra.

Juozas AUGUTIS. Dr Habil, Vice-Rector for Science and Research, Prof. of Department of Mathematics and Statistics, Vytautas Magnus University, Chief Research Assoc. of Laboratory of Nuclear Installation Safety, Lithuanian Energy Institute. Doctor Habil of Technological Sciences, 2003, Lithuanian Energy Institute; PhD in Mathematics, 1986, Vilnius University. Employment: Professor (2006), Associate Professor (1990). Publications: author of 1 monograph, over 90 research papers. Research interests: energy security, reliability theory, risk analysis, probabilistic safety analysis. Honorary awards and membership: prize-winner of the Republic of Lithuania (2005), expert member of Lithuanian Academy of Sciences. Expert in Lithuanian State Science and Studies Foundation, expert in Science Council of Lithuania, expert in The Sixth Framework Programme for Research and Technological Development.

Ričardas KRIKŠTOLAITIS. Dr, Assoc. Prof. of Department of Mathematics and Statistics, Vytautas Magnus University, Senior Research Assoc. of Laboratory of Nuclear Installation Safety, Lithuanian Energy Institute. PhD in Mathematics, 2001, Vytautas Magnus University. Employment: Associate Professor (2007). In 2005 was in 6 month internship in Joint Research Centre Institute for Transuranium Elements, Karlsruhe, Germany. Publications: 1 educational book, over 20 research papers. Research interests: reliability analysis of power system, security of energy supply, statistical data analysis.

Sigita PEČIULYTĖ. Dr, Assoc. Prof. of Department of Mathematics and Statistics, Vytautas Magnus University. PhD in Mathematics, 2007, Vilnius Gediminas Technical University. Publications: over 15 research papers. Research interests: security of energy supply, differential problems with nonlocal conditions.

Inga KONSTANTINAVIČIŪTĖ. Dr, Senior Research Associate of Laboratory of Energy Systems Research, Lithuanian Energy Institute, and Assoc. Prof. of Department of Electric Power Systems, Kaunas University of Technology. PhD in Energy and Thermal Engineering, 2000, Kaunas University of Technology. Publications: over 20 research papers. Research interests: energy demand forecasting, analysis of energy policy instruments for RES promotion, environmental regulations of energy sector. 